\title{
Leaf phenology and insect grazing of Japanese white birch saplings grown under free-air ozone exposure
}

\author{
Tetsuichi SAKIKAWA ${ }^{\mathrm{a}}$, Cong SHI $^{\mathrm{a}}$, Masahiro NAKAMURA ${ }^{\mathrm{b}}$, Makoto WATANABE ${ }^{\mathrm{c}}$, \\ Monta OIKAWA $^{\mathrm{a}}$, Fuyuki SATOH ${ }^{\mathrm{b}}$ and Takayoshi KOIKE ${ }^{\mathrm{a}, \dot{\dagger}}$ \\ ${ }^{a}$ Silviculture \& Forest Ecological Studies, Hokkaido University, Sapporo 060-8589, Japan \\ ${ }^{\mathrm{b}}$ Field Science Center for Northern Biosphere, Hokkaido University, Sapporo 060-0809, Japan \\ ${ }^{\mathrm{c}}$ Tokyo University of Agriculture and Technology, Tokyo 183-8509, Japan
}

\begin{abstract}
Ground-level ozone $\left(\mathrm{O}_{3}\right)$ increases yearly and negatively affects the growth of birches via leaf dynamics. Leaf area is directly related to plant production and is usually reduced by elevated $\mathrm{O}_{3}\left(\mathrm{eO}_{3}\right)$ and insect herbivores. The objective of this study was to explore factors affecting change in leaf number of white birch saplings and insects grazing under $\mathrm{eO}_{3}$. In order to accomplish this objective, we observed seasonal changes in leaf phenology and determined foliar defense chemicals in saplings grown under ambient air and free-air $\mathrm{O}_{3}$ enrichment $\left(60 \mathrm{nmol} \mathrm{mol}^{-1}\right.$ for daytime $)$. The leaf phenology showed the total number of emerged leaves was about 10 per shoot in the control and $\mathrm{eO}_{3}$ plots. However, the number of attached leaves per shoot at ambient air decreased after mid-July, probably due to grazing by larvae of the leaf beetle. In addition, the concentration of condensed tannin in early leaves was higher in the $\mathrm{eO}_{3}$ plot than that in the control plot. Such leaves with decreased nutritional value under $\mathrm{eO}_{3}$ may prevent feeding of leaf beetles. These findings lead to the plausible understanding of an indirect effect of $\mathrm{eO}_{3}$ on leaf phenology via foliar defense of white birch against insect herbivores.
\end{abstract}

Key words: Free- $\mathrm{O}_{3}$ enrichment, Grazing, Leaf beetle, Plant defense, White birch.

\section{Introduction}

Ground-level ozone $\left(\mathrm{O}_{3}\right)$ has been increasing in Japan because of high emissions of its precursors under rapid economic development (Akimoto, 2003; Yamaji et al., 2008; Ohara, 2011). The Acid Deposition and Oxidant Research Center (ADORC, 2006) suggested that elevated $\mathrm{O}_{3}\left(\mathrm{eO}_{3}\right)$ levels in Japan might have negative impacts on forest trees and their photosynthetic production. According to other studies (Watanabe et al., 2013, 2014), $\mathrm{eO}_{3}$ can cause a decline of photosynthetic capacity and an increase of respiration in Siebold's beech (Fagus crenata) and oak (Quercus mongolica var. crispula) trees. Plant production is highly related to the leaf area index (LAI) and the photosynthetic activity (e.g. Larcher, 2003). As, LAI is strongly influenced by biotic and abiotic stresses (Orcutt and Nilsen, 2000), more knowledge is required regarding factors affecting $\mathrm{LAI}$ in the field.

Izuta et al. (2001) reported that $\mathrm{eO}_{3}$ alters the physiological functions of plants and their defense against pests, probably because $\mathrm{eO}_{3}$ leads to increase concentrations of phenolics via oxidation of fatty acid of leaf cell membrane (Yamaji et al., 2006; Valkama et al., 2007; Oksanen et al., 2009; Lindroth, 2010; Matyssek et al., 2012). Therefore, $\mathrm{eO}_{3}$ may affect the LAI by impacting the defense against insect herbivores.

White birch is a typical pioneer tree species in cool temperate regions and widely used for re-vegetation in northern Japan (Koike, 1995). It has heterophyllous leaves; it flushes early

Received; July 4, 2014.

Accepted; January 21, 2016.

†Corresponding Author: tkoike@for.agr.hokudai.ac.jp

DOI: 10.2480/agrmet.D-14-00031 leaves in spring and then, after the complete expansion of early leaves, develops late leaves (Koike, 1995). Nowadays, the grazing damage to white birch by larvae of leaf beetle (Agelastica coerulea) is increasing in northern Japan (Sayama et al., 2014) .

In Hokkaido, northern Japan, $\mathrm{O}_{3}$ concentration is increased from spring to early summer (Ohara, 2011). The preference in oviposition and larval feeding of the leaf beetle might be altered by $\mathrm{eO}_{3}$ due to the diminishing of photosynthetic production (Hoshika et al., 2013) and a the consequently reduced plant defense. To test this, we observed the leaf phenology and determined the concentrations of foliar defense chemicals in leaves of white birch saplings grown in a free-air $\mathrm{O}_{3}$ fumigation system. Based on our findings, we discuss a plausible understanding of leaf phenology under $\mathrm{eO}_{3}$ in relation to the insect herbivores.

\section{Materials and Methods}

\subsection{Experimental plot and Plant material}

This study was conducted in the free-air- $\mathrm{O}_{3}$ enrichment system established at Sapporo Experimental Forest, Hokkaido University, in northern Japan $\left(43^{\circ} 04^{\prime} \mathrm{N}, 141^{\circ} 20^{\prime} \mathrm{E}, 15 \mathrm{~m}\right.$ a.s.l.). This forest is located on flatland. The study sites were equipped with brown forest soil, ambient air and another for $\mathrm{eO}_{3}$, with a distance of 24 $\mathrm{m}$ between them. Each size was $5.5 \times 7.2 \mathrm{~m}$. Three-year-old saplings of Japanese white birch (Betula platyphylla var. japonica) were planted in each plot in 2011. In the spring of 2013, the mean tree height was $3.0 \pm 0.4 \mathrm{~m}$, and the mean stem diameter at breast height was $15.5 \pm 2.1 \mathrm{~mm}$. Ten saplings were subjected to $\mathrm{O}_{3}$ treatments from August to November 2011, and from May to November 2012 and 2013.

The targeted $\mathrm{O}_{3}$ concentration was $60 \mathrm{nmol} \mathrm{mol}^{-1}$ during daytime, which is the standard of the Japanese environment (ADORC, 
2006). The regulation of the operation was attained using a light sensor with a cut-off of light compensation point (LCP) over 60 $\mu \mathrm{mol} \mathrm{m} \mathrm{m}^{-2} \mathrm{~s}^{-1}$, as determined previously (Koike, 1988). The $\mathrm{O}_{3}$ concentration at the canopy height was monitored continuously by an $\mathrm{O}_{3}$ monitor (Mod. 202, 2B Technologies, Boulder, CO, U.S.A.), and the observed value was used as a feedback to the three-way valve to regulate the $\mathrm{O}_{3}$ concentration the PID algorithm. The average $\mathrm{O}_{3}$ concentrations during daytime in the control and $\mathrm{eO}_{3}$ treatment plots were 26.5 and $53.8 \mathrm{nmol} \mathrm{mol}^{-1}$, respectively. The targeted $\mathrm{O}_{3}$ concentration was satisfactorily regulated, especially at relatively low wind speeds. More details can be found in Watanabe et al. (2013).

\subsection{Monitoring of leaf phenology}

The leaf developmental pattern of middle crown exposed to sunshine was monitored in 8 to 9 individuals in each plot, at a 1to 3 -week interval during the growing season of 2013. For each plot, we used steal jungle gym towers with $6.0 \times 7.5 \times 6.0 \mathrm{~m}$ in size. A survey of the number of leaves was conducted at the terminal shoot of the saplings, according to the observation method of Ito et al. (2011). Namely, the average number of leaves per shoot was calculated according to Kikuzawa (1978) and Kikuzawa and Lechowicz (2011). The defoliation was measured as the number of shed leaves (Hensel et al., 1993). Finally, this information of the dynamics of leaf number per selected shoot (=leaf phenology) specified the number of total emerged leaves per shoot.

\subsection{Insect behavior and defensive chemicals}

According to Ikenoya (2006), the life cycle of the leaf beetle (Agelastica coerulea Baly) is as follows: adults overwinter under a shallow part of soil and litter; appear and start grazing leaves of alder and birch from late April to early June (in central Hokkaido island); and make ovipositing eggs on the abaxial side of leaves from June. Then, hatched larvae start to graze leaves from early July to early September; they move very slowly in a limited area on a leaf or hatched leaf. Insect grazing by larvae of the leaf beetle was visually observed in July. However, we did not measure the population dynamics of adults and larvae of the beetle at each treatment. Additionally, information on the oviposition behavior, such as the sex identification of adults and oviposition or hatching rate, was not observed.

For the determination of the concentration of total phenolics and condensed tannin, 4 to 6 early and late leaves were collected in August of 2013. On May, 2 or 3 leaves of each bud on the saplings started flush: these are classified as early leaves. Leaves flushed in the first week of June and July were used as late leaves. The Folin-Ciocalten method and proanthocyanidin method were applied for the determination (Bate-Smith, 1977; Julkunen-Tiitto, 1985).

\subsection{Statistical analysis}

The effect of $\mathrm{eO}_{3}$ on the number of leaves per shoot and the concentrations of total phenolics and condensed tannin were analyzed using a t-test. Statistical analyses were performed using SPSS Statistics ver.12 (IBM, USA). Results were considered significant at $P<0.05$ and marginal at $P<0.10$.

\section{Results}

\subsection{The number of total leaves per shoot}

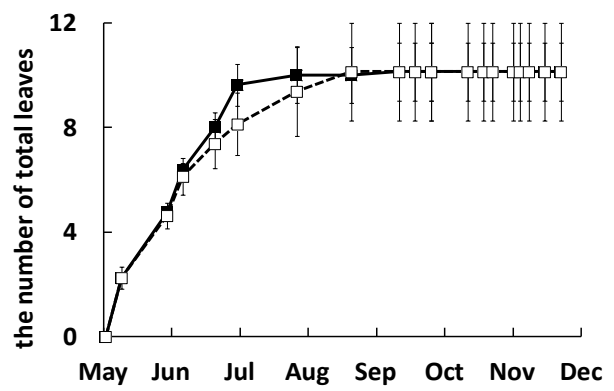

Fig. 1. Cummulative number of leaves per shoot of white birch saplings. Closed square: ambient, open square: $\mathrm{O}_{3}$ treatment, Data are represented as mean $\pm \operatorname{SE~}(n=8)$

In the late growing season, the control and $\mathrm{eO}_{3}$ treatment plots had a cumulative average of 10 total leaves per shoot, as shown in Fig. 1. There was no significant difference in the cumulative leaf number. By late May, shoots were composed of early leaves. From early June, several late leaves gradually emerged.

\subsection{The number of attached leaves per shoot}

A marginal difference in the number of attached leaves per shoot was observed between the control and $\mathrm{eO}_{3}$ plots from midAugust to early October (Fig. 2: $P<0.10$ ). In the control plot, the number of attached leaves per shoot decreased rapidly from midJuly. As a result, the average number of attached leaves in the control and $\mathrm{eO}_{3}$ treatment plots was $5.4( \pm 1.1)$ and $9.9( \pm 1.9)$, respectively, from September to October. Leaf falling in both plots lasted until early November.

\subsection{Grazing by leaf beetles}

Adult leaf beetles were observed in both plots from early May, but very few individuals of larvae were found on each leaf in the $\mathrm{eO}_{3}$ treatment plot. Accordingly, fewer grazing symptoms of leaves by larvae of the leaf beetle were found in the $\mathrm{eO}_{3}$ treatment plot than in the control plot.

\subsection{Defensive chemical compounds}

A marginal difference in the concentration of condensed tannin between the control and $\mathrm{eO}_{3}$ treatment plots was observed only in early leaves (Fig. 3: $P=0.08$ ). As shown in Table 1, the concentration of condensed tannin in early leaves in the $\mathrm{eO}_{3}$ plot was

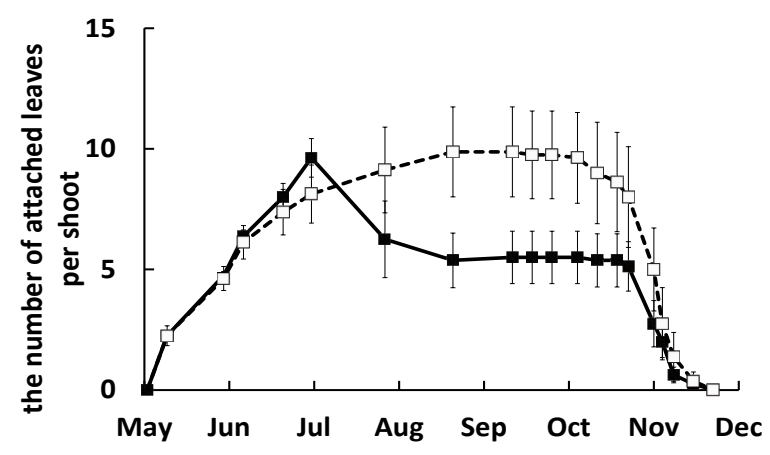

Fig. 2. Number of attached leaves per shoot of white birch saplings. Closed square: ambient, open square: $\mathrm{O}_{3}$ treatment, Data are represented as mean $\pm \mathrm{SE}(\mathrm{n}=8)$. t-test: $\dagger$ : $\dagger: P<0.10$ 


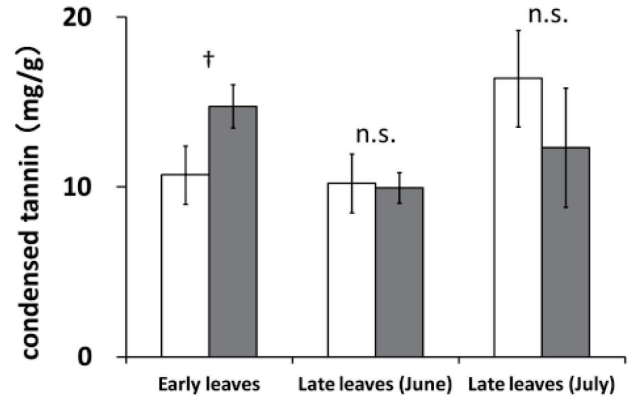

Fig. 3. Concentration of condensed tannin of early and late leaves of white birch saplings.

$\square$ : ambient $\mathbf{~}: \mathrm{O}_{3}$ treatment, Data are represented as mean $\pm \mathrm{SE}(\mathrm{n}=4-6)$. t-test: $\mathrm{n} . \mathrm{s}$. no significant, $\dagger: P<0.10$

about $4.0 \mathrm{mg} \mathrm{g}^{-1}$ higher than that in early leaves in the control plot, although there was no significant or marginal difference between the treatments in late leaves. However, as shown in Fig. 4, no significant difference was found in the total phenolics $(\approx 50 \mathrm{mg}$ $\mathrm{g}^{-1}$ ) in early and late leaves between the control and $\mathrm{eO}_{3}$ plots.

\section{Discussion}

We expected that $\mathrm{eO}_{3}$ would decrease the number of late leaves per shoot of white birch because late leaves are developed using current photo-assimilates of the early leaves (Koike, 1995). As found by Hoshika et al. (2013) in the same species, the photosynthetic activity of early leaves was suppressed by elevated $\mathrm{eO}_{3}$. Thus, the photo-assimilates of the early leaves may limit the development of late leaves. Likely, the production of defensive chemicals may be diminished.

However, there was no significant difference in the cumulative number of leaves per shoot between the control and $\mathrm{eO}_{3}$ plots, which implies that $\mathrm{eO}_{3}$ enrichment of previous years did not have an impact on the formation of leaf primordia. A similar trend was found in another experiment in which poplar clones were fumigated with different $\mathrm{O}_{3}$ concentrations in open-top chambers in central Europe (Matyssek et al., 1993).

Moreover, the number of attached leaves under ambient air started to decrease sharply from mid-July to August, as shown in Fig. 2. This difference in leaf shedding may be attributed to grazing by the larvae of the leaf beetle. Generally, when leaves are grazed by insect herbivores, plants usually shed the grazed leaves

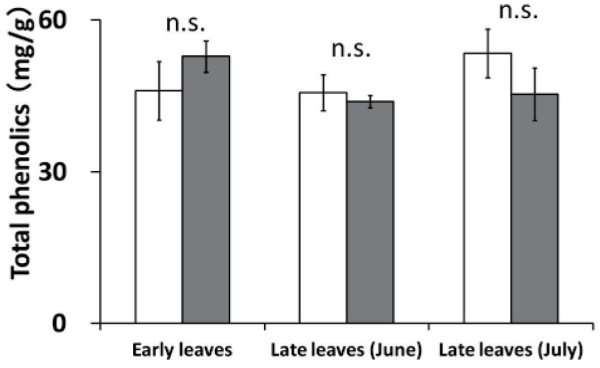

Fig. 4. Concentration of total phenolics of early and late leaves of white birch saplings.

$\square$ : ambient $\mathbf{~} \mathrm{O}_{3}$ treatment, Data are represented as mean \pm SE ( $n=4-6)$.t-test: n.s. no significant

in order to avoid further damage and the cost of keeping these damaged leaves (Schoonhoven et al., 1998; Kikuzawa, 2005). We observed that leaves were grazed by the leaf beetles, especially by its skeletonizer larvae (grazing leaf surface avoid veins) However, we did not find any leaves grazed by larvae of the leaf beetle under $\mathrm{eO}_{3}$, which raises a question about what happened to the susceptibility of white birch to leaf beetles with and without $\mathrm{eO}_{3}$. We cannot clarify that the decrease of attached leaves was mainly a result of the shed of the early or late leaves. Visual observations, however, showed that larvae mainly grazed late leaves.

In general, adult leaf beetles start to graze early leaves from May to June and lay ovipositing eggs on leaves from June. Larvae hatch from the eggs and begin grazing leaves from July, and then adults resume chewing leaves from late August to September (Ikenoya, 2006; Oikawa et al., 2012).

As shown in Fig. 3, saplings under $\mathrm{eO}_{3}$ produced a high concentration of condensed tannin in early leaves. According to previous meta-analyses, $\mathrm{eO}_{3}$ treatment has been shown to enhance the activities of phenylalanine-ammonium lyase and chalcone synthase enzymes that regulate phenylpropanoid and flavonoid biosynthesis pathways (grazing leaf surface avoid veins). These pathways play an essential role in plant defense responses because they synthesize several potentially protective compounds, such as flavonoids and other phenolics, which act as scavengers of various oxygen species such as superoxide anion, singlet oxygen, and hydroxyl radicals (grazing leaf surface avoid veins). Tannin strongly inhibits digestion in the leaf beetle (Schoonhoven et al.,

Table 1. Data of concentration of total phenolics and condensed tannin. Each value denotes the mean $( \pm \mathrm{SD})$ of $4-6$ replicated The level of of significance $(P$ value $)$ of t-test.

\begin{tabular}{lcccc}
\hline & & Early leaves & Late leaves $($ June $)$ & Late leaves $($ July $)$ \\
\hline \multirow{3}{*}{ Total phenolics $(\mathrm{mg} / \mathrm{g})$} & Ambient & $46.0(11.6)$ & $45.6(7.2)$ & $53.5(9.6)$ \\
& $\mathrm{O}_{3}$ & $52.8(6.2)$ & $43.9(2.4)$ & $45.4(10.5)$ \\
& $P$ value & 0.32 & 0.57 & 0.27 \\
\hline \multirow{3}{*}{ Condensed tannin $(\mathrm{mg} / \mathrm{g})$} & $\mathrm{Ambient}$ & $10.7(3.4)$ & $10.2(3.5)$ & $16.4(5.7)$ \\
& $\mathrm{O}_{3}$ & $14.7(2.6)$ & $9.9(1.8)$ & $12.3(7.0)$ \\
& $P$ value & 0.08 & 0.86 & 0.37 \\
\hline
\end{tabular}


1998), therefore the early leaves of the saplings had decreased nutritional values for the leaf beetles under $\mathrm{eO}_{3}$ (Hinata, 2010).

It is possible that the adult female of leaf beetles avoid ovipositing on leaves under $\mathrm{eO}_{3}$, which could explain why no leaves were grazed by the larvae of the leaf beetle under $\mathrm{eO}_{3}$. The larvae could not move between each plot. A similar study revealed that the leaf beetle avoids ovipositing on the leaves of cottonwood (Populus deltoids) exposed to elevated $\mathrm{O}_{3}$ (Jones and Coleman, 1988). Another study explained that this avoidance by adult females could be due to the production of various substances by plants, such as biogenic volatile organic compounds (BVOCs) (e.g. Yamaji et al., 2006), that act as an "infochemical" (Fares et al., 2010; Lindroth, 2010) used to attract or repel leaf beetles. However, we did not observe the seasonal changes of the rates of mortality and birth of adult beetles as well as their ovipositing behavior. It is also possible that $\mathrm{eO}_{3}$ or BVOCs emitted from the leaf surface (Niinemets and Monson, 2013) may directly impact leaf beetles and change their behaviors. These possibilities should be tested in future studies.

The results of the present study show that $\mathrm{eO}_{3}$ altered the leaf phenology via changes in ovipositing preference or larval feeding of the leaf beetle. This probably happened because $\mathrm{eO}_{3}$ enhanced the foliar defense against insect herbivores.

\section{Acknowledgements}

We thank Dr. Kentaro Takagi for his proper guidance. This work was supported by the Environment Research and Technology Development Fund (B-1105) of the Ministry of the Environment in Japan through Prof. T. Izuta of Tokyo University of Agriculture and technology, and the Young Scientists B (24710027 to M.W.) and Basic research (Type B: 26292075 to T.K., Type C: 26450188 to M.N) programs of a Grant-in-Aid of the Japan Society for the Promotion of Science. We thank Mr. Eugenios Agathokleous of JSPS fellowship and Dr. Anthony Garrett of The SCITEX of Cambridge, U.K. for English proofreading.

\section{References}

ADORC (Acid deposition and oxidant research center), 2006: Tropospheric ozone a growing threat. Niigata, pp. 26. (in Japanese)

Akimoto, H., 2003: Global air quality and pollution. Science, 302, 1716-1719.

Bate-Smith, E. C., 1977: Astringent tannins of Acer species. Phytochemistry, 16, 1421-1426.

Fares S., Oksanen, E., Lännenpaa, M., Julkunen-Tiitto, R., and Loreto, F., 2010: Volatile emissions and phenolic compound concentrations along a vertical profile of Populus nigra leaves exposed to realistic ozone concentrations. Photosynthesis Research, 104, 61-74.

Hensel, L., Grbic, V., Baumgarten, D. A., and Bleecker, A. B., 1993: Development and age-related processes that influence the longevity and senescence of photosynthetic tissues in Arabidopsis. The Plant Cell, 5, 553-564.

Hinata, K., 2010: Study on the localization of defense chemicals in leaves of deciduous broad-leaved tree seedlings under changing environment. Master thesis of Graduate School of Agriculture of Hokkaido University, pp. 48. (in Japanese)

Hoshika, Y., Watanabe, M., Inada, N., Mao, Q., and Koike, T.,
2013: Photosynthetic response of early and late leaves of white birch (Betula platyphylla var. japonica) grown under free-air ozone exposure. Environmental Pollution, 182, 242-247.

Ikenoya, S., 2006: Leaf beetle. Atlas of Disease, Insect grazing and Damage by animal in Hokkaido by Hokkaido Forestry Research Institute. Hokkaido forest and green, Sapporo. 135. (in Japanese)

Ito, H., Watanabe, M., Mao, Q., Novriyanti, E., Ueda, T., Takagi, K., Sasa, K., Saito, H., Shibuya, M., and Koike, T., 2011: Shoot dynamics of 3 birch seedlings grown under a Free Air $\mathrm{CO}_{2}$ Enrichment system. Hokkaido Branch of Japanese Journal of Forestry Society, 59, 35-38. (in Japanese)

Izuta, T., Matsumura, H., Kohno, Y., and Shimizu, H., 2001: Experimental studies on the effects of ozone on forest tree species. Journal of Japanese Society of Atmospheric Environment, 36, 60-77. (in Japanese)

Jones, C. G., and Coleman, J. S., 1988: Plant stress and insect behavior: Cottonwood, ozone and the feeding and oviposition preference of a beetle. Oecologia, 76, 51-56.

Julkunen-Tiitto, R. 1985: Phenolic constituents in the leaves of northern willows: methods for the analysis of certain phenolics. Journal of Agriculture and Food Chemistry, 33, 213-217.

Kikuzawa, K., 1978: Survival curve of the leaves of several hardwoods. Journal of Japanese Forestry Society, 89, 187-188. (in Japanese with English summary)

Kikuzawa, K., 2005: Ecology of leaf longevity: from individual leaves to ecosystems, Kyoritsu Publisher, Tokyo, pp. 212. (in Japanese)

Kikuzawa, K., and Lechowicz, M. J., 2011: Ecology of Leaf Longevity, Springer, Tokyo, pp.147.

Koike, T. 1988: Leaf structure and photosynthetic performance as related to the forest succession of deciduous broad-leaved trees. Plant Species Biology, 3, 77-87.

Koike, T., 1995: Physiological ecology of the growth characteristics of Japanese mountain birch in Northern Japan: a comparison with Japanese white birch. Vegetation Science in Forestry: Global Perspective based on Forest Ecosystems of East \& Southeast Asia (ed. by Box, E. O., Peet, R. K., Masuzawa, T., Yamada, I., Fujiwara, K. and Maycock, P. F.), Kluwer Academic Publishers, The Netherlands, pp.409-422.

Larcher, W., 2003: Plant Physiological Ecology, 4th edition, Springer Verlag, Heidelberg, pp. 513.

Lindroth, R. L., 2010: Impacts of elevated atmospheric $\mathrm{CO}_{2}$ and ozone on forest: Phytochemistry, trophic interactions and ecosystem dynamics. Journal of Chemical Ecology, 36, 2-21.

Matyssek, R., Keller, Th., and Koike, T., 1993: Branch growth and leaf gas exchange of Populus tremula exposed to low ozone concentration throughout two growing seasons. Environmental Pollution, 79, 1-7.

Matyssek, R., Schnyder, H., Oßwald, W., Ernst, D., Munch, J. C., and Pretzsch, H., 2012: Growth and defence in plants. Resource allocation at multiple scales. Springer Ecological Studies. 220, Heidelberg, pp.470.

Niinemets, Ü., and Monson, R. K., 2013: Biology, controls and models of tree volatile organic compound emissions. Springer Verlag, Heidelberg, pp.547.

Ohara, T., 2011: Why is the increase of tropospheric ozone concentration in mountain and island regions in Japan? Japanese Journal of Ecology, 61, 77-81. (in Japanese)

Oikawa, M., Matsuki, S., Saito, H., Shibuya, M., and Koike, T., 2012: Survivorships of insect herbivores with different food habit on deciduous broad leaved trees. Boreal Forest Research, 
60, 111-112. (in Japanese)

Oksanen, E., Manninen, S., Vapaavuori, E., and Holopainen, T., 2009: Near-ambient ozone concentrations reduce the vigour of Finnish deciduous trees, Betula and Populus species. AMBIO, 38, 413-417.

Orcutt, D. M., and Nilsen, E. T., 2000: The physiology of plants under stress: Soil and biotic factors, Wiley, pp.696.

Sayama, K., Ozaki, K., Hara, A., and Onodera, K., 2014: Forest insect appear in Hokkaido in 2014, Northern Forestry, 66, 143145. (in Japanese)

Schoonhoven, L. M., Jeremy, T., and Van Loon, J. J. A., 1998: Insect-plant biology. (ed. by Chapman and Hall). London. pp.409.

Valkama, E., Koricheva, J., and Okasanen, E., 2007: Effects of elevated $\mathrm{O}_{3}$, alone and in combination with elevated $\mathrm{CO}_{2}$, on tree leaf chemistry and insect herbivore performance: a metaanalysis. Global Change Biology, 13, 184-201.
Watanabe, M., Hoshika, Y., Inada, N., and Koike, T., 2014: Canopy carbon budget of Siebold's beech (Fagus crenata) saplings exposed to ozone. Environmental Pollution, 184, 682-689. Watanabe, M., Hoshika, Y., Inada, N., Wang, X. N., Mao, Q. Z., and Koike, T., 2013: Photosynthetic traits of Siebold's beech and oak saplings grown under free air ozone exposure in northern Japan. Environmental Pollution, 174, 50-56.

Yamaji, K., Ohara, T., Uno, I., Kurokawa, J., Pochanart, P., and Akimoto, H., 2008: Future prediction of surface ozone east Asia using models-3 community multiscale air quality modeling system and regional emission inventory in Asia. Journal of Geophysical Research, 113, D08306.

Yamaji, K., Oksanen, E., Julkunen-Tiitto, R., Rousi, M., 2006: Variation of phenolic compounds in Birch leaves exposed to ozone. Tree sap III (ed. by Terazawa M), Hokkaido University Press, Sapporo, pp.141-147. 